\title{
ANALISIS KEMAMPUAN BERPIKIR INTUITIF SISWA YANG MEMILIKI GAYA BELAJAR TIPE JUDGING DALAM MENYELESAIKAN SOAL MATEMATIKA DI KELAS X SMA NEGERI 5 BATANGHARI
}

\author{
Khodriyah $^{1}$, Sri Dewi ${ }^{2}$, Hasan Basri Said ${ }^{3}$ \\ Program Studi Pendidikan Matematika, FKIP, Universitas Batanghari ${ }^{1,2,3}$ \\ Jl. Slamet Riyadi No.1 Broni Jambi \\ e-mail: -
}

\begin{abstract}
ABSTRAK
Tujuan dari penelitian ini adalah untuk menganalisis dan menggambarkan karakter siswa berpikir intuitif dari jenis gaya belajar menilai dalam memecahkan masalah matematika. Jenis penelitian yang digunakan adalah penelitian kualitatif deskriptif. Subjek penelitian ini adalah siswa kelas X SMA Negeri 5 Batanghari dengan total 161 siswa. Metode pengumpulan data yang digunakan dalam penelitian ini adalah metode tes dan metode wawancara. Instrumen penelitian dalam penelitian ini adalah peneliti itu sendiri sedangkan instrumen lainnya adalah kuesioner MBTI (Myers Briggs Type Indicator) yang diadopsi langsung dari buku Tim Psikologi (Babon Psikotes Paling Update), nilai hasil belajar siswa, lembar tes matematika, dan pedoman wawancara. Proses berpikir intuitif dalam menyelesaikan masalah matematika dari subjek penelitian diungkapkan melalui observasi dan wawancara berdasarkan pada lembar tugas kemampuan berpikir intuitif dalam memecahkan masalah matematika di mana lembar tugas kemampuan berpikir intuitif siswa dalam menyelesaikan masalah matematika dan pedoman wawancara divalidasi oleh validator Data dianalisis berdasarkan indikator untuk menyelesaikan masalah matematika menurut Polya yang meliputi (1) memahami masalah (2) merencanakan penyelesaian masalah (3) menerapkan rencana penyelesaian masalah (4) meninjau kebenaran masalah yang telah dibuat dan indikator berpikir intuitif diamati menurut Westcott yaitu (1) inferensi katalitik (2) kekuatan sintesis (3) pengertian cammon. Hasil penelitian menunjukkan bahwa (1) karakter berpikir intuitif yang digunakan oleh STJ dalam menyelesaikan pertanyaan SPLTV termasuk: rasa cammon, globalitas, kepastian intrinsik dan ketekunan. (2) karakter berpikir intuitif yang digunakan oleh SSJ dalam memecahkan masalah SPLTV meliputi: cammon sence, globality.
\end{abstract}

\section{Kata kunci:}

Kemampuan Berpikir Intuitif, Menilai Gaya Belajar, Masalah Matematika, Materi Sistem Persamaan Linear Tiga Variabel.

\begin{abstract}
The purpose of this study was to analyze and describe the characters of intuitive thinking students of the type of learning style of judging in solving math problems. The type of research used is descriptive qualitative research. The subject of the study was the tenth grade students of Batanghari 5 State Senior High School with a total of 161 students. Data collection methods used in this study are test methods and interview methods. The research instrument in this study was the researcher himself while the other iinstrument were the MBTI (Myers Briggs Type Indicator) questionnaire which was adopted directly from the Tim Psikologi (Babon Psikotes Paling Update) book, the value of student learning outcomes, mathematics test sheets, and interview guidelines. Intuitive thinking process in solving mathematical problems from the research subject was revealed through observation and interviews based on the task sheet of intuitive thinking ability in solving math problems where the task sheets of students' intuitive thinking ability in completing math problems and interview guidelines were validated by validator. The data were analyzed based on indicators to solve mathematical problems according to the Polya which included (1) understanding the problem (2) planning the completoin of the problem (3) implementing the problem solving plan (4) reviewing the correctness of the problem that had been made and the intuitive thinking indicator observed according to Westcott namely (1) catalic inference (2) power of synthesis (3) cammon sense. The results showed that (1)
\end{abstract}


the intuitive thinking characters used by STJ in solving SPLTV questions included: cammon sense, globality, intrinsic certainty and perseverance. (2) the intuitive thinking characters used by SSJ in solving SPLTV problems include: cammon sence, globality.

Keywords:

Intuitive Thinking Ability, Judging Learning Style, Math Problem, Material Three-Variable Linear Equation System.

\section{PENDAHULUAN}

Matematika merupakan salah satu ilmu yang diajarkan pada setiap jenjang pendidikan, mulai dari pendidikan dasar, pendidikan menengah dan perguruan tinggi. Salah satu tujuan pembelajaran matematika adalah membantu siswa untuk berpikir dan bernalar secara kreatif. Hampir setiap siswa pada saat memahami atau menyelesaiakan masalah matematika memerlukan waktu atau strategi penyelesaian yang berbeda. Ada siswa yang memilih langkah formal atau analitis (seperti menggunakan rumus dan aturan logika), kemudian jika masalahnya dianggap asing atau bahkan sama sekali tidak ada hubungannya dengan pengetahuan informal, siswa dapat menyelesaikan secara langsung (directly). Kemampuan seseorang memahami dan sekaligus menemukan strategi yang tepat dan cepat dalam menyelesaikan masalah merupakan kecakapan berpikir intuitif yang muncul secara spontan atau muncul secara tibatiba (sudently) dan tidak diketahui dari mana asalnya (Fitriani, 2015).

Menurut Fischben, 1994 (Usodo, 2012) aktivitas mental yang berbeda dari kognisi formal tersebut disebut intuisi.Pendapat lain dari Dreyfus T. dan Eisenberg T., 1982 (Muniri, 2013) mengatakan bahwa pemahaman secara intuitif sangat diperlukan sebagai "jembatan berpikir" manakala seseorang berupaya untuk menyelesaikan masalah dan memandu menyelaraskan kondisi awal dan kondisi tujuan. Siswa dengan kemampuan intuitif ini sesuai dengan tujuan kurikulum 2013 yang mana salah satunya adalah mengembangkan berbagai sikap, pengetahuan, dan keterampilan.

Gaya belajar merupakan faktor intern yang terdapat dalam diri siswa yang sangat berpengaruh terhadap hasil siswa (Fitriani, 2017). Gaya belajar menurut MBTI bersandar pada empat tipe kepibadian yang saling berlawanan sehingga terdapat delapan tipe kepribadian yaitu extrovert, introvert, sensing, intuition, thinking, feeling, judging, perceiving. Gaya belajar siswa memiliki karakter yang berbeda-beda. Dalam hal ini, peneliti tertarik untuk melihat kemampuan berpikir intuitif siswa sesuai dengan tipe gaya belajar yang paling dominan yang dimiliki siswa tersebut. Apakah siswa yang mempunyai gaya belajar tipe tertentu juga mempunyai kemampuan untuk berpikir intuitif.

Dari hasil wawancara dengan guru mata pelajaran matematika yang mengajar di SMA Negeri 5 Batanghari ini diketahui dalam proses pembelajaran dan melihat jawaban latihan soal dari siswa, siswa kurang mampu menggunakan kemampuan berpikir intuitif dikarenakan siswa tidak pernah diajarkan untuk berpikir intuitif, apalagi siswa cenderung untuk mengikuti cara yang diberikan oleh guru mata pelajaran tersebut. Walaupun terkadang dalam menjawab pertanyaan secara lisan ia terlihat memakai intuisinya, tetapi dalam menjawab pertanyaaan secara tertulis ia tidak menggunakan intuisinya. 


\section{$\pi$ (Phi)}

\section{METODE PENELITIAN}

Penelitian ini dikategorikan sebagai penelitian kualitatif dengan pendekatan penelitian kualitatif deskriptif. Penelitian ini akan dilaksanakan pada siswa kelas X SMA Negeri 5 Batanghari. Hal yang dideskripsikan adalah kemampuan berpikir intuitif siswa tipe judging pada saat menyelesaikan soal matematika.Pendeskripsian ini ditelusuri melalui pengamatan langsung terhadap subjek penelitian dalam menyelesaikan soal matematika yaitu langkah-langkah yang dikerjakan oleh subjek penelitian. Selain itu, pendeskripsian ini juga dilakukan dengan cara wawancara semi struktur.

Wawancara dalam penelitian ini bertujuan untuk mengetahui gambaran kemampuan berpikir intuitif siswa yang memiliki gaya belajar tipe judging dalam menyelesaikan soal matematika.

$$
\bar{x}=\frac{\sum f_{i} x_{i}}{n}
$$

c. Menentukan batas kelompok

Tabel 1. Kriteria Pengelompokkan Siswa Berdasarkan Hasil Tes Kesulitan Belajar Matematika

\begin{tabular}{cc}
\multicolumn{2}{c}{ dalam Menyelesaikan Soal Matematika } \\
\hline Nilai (x) & Kelompok \\
\hline$x \geq \bar{x}+$ DS & Tinggi \\
$\bar{x}-\mathrm{DS}<x<\bar{x}+$ DS & Sedang \\
$\bar{x}-\mathrm{DS} \geq x$ & Rendah \\
\hline
\end{tabular}

Penelitian ini dilaksanakan di SMA Negeri 5 Batanghari kelas $\mathrm{X}$ tahun ajaran 2017/2018. Waktu penelitian dilaksanakan pada semester ganjil tahun ajaran 2017/2018.

Subjek penelitian ini adalah siswa dengan gaya belajar yang dominan yaitu gaya belajar judging. Pemilihan subjek penelitian ini berdasarkan angket gaya belajar menurut MBTI (Myers- Briggs Type Indicator).Adapun teknik pengambilan sampel berdasarkan pada nilai UH siswa (tinggi dan sedang). Arikunto (2010) menjelaskan langkahlangkah mengelompokkan siswa dalam kemampuan tinggi, sedang, dan rendah sebagai berikut:

a. Menjumlahkan semua nilai matematika dari hasil UH siswa

b. Mencari nilai rata-rata (mean) dan simpangan baku (deviasi standar) menggunakan rumus:

$$
\mathrm{DS}=\sqrt{\frac{\sum f_{i} x_{i}{ }^{2}}{n}-\left(\frac{\sum f_{i} x_{i}}{n}\right)^{2}}
$$

Pada penelitian ini teknik pengumpulan data yang digunakan adalah triangulasi.Triangulasi adalah teknik pengumpulan data yang bersifat menggabungkan dari berbagai teknik pengumpulan data dan sumber data yang telah ada.Triangulasi yang digunakan adalah triangulasi teknik.

Pada lembar tes gaya belajar, terdapat beberapa sikap atau kebiasaan yang menjadi karakterisktik belajar.
Setiap siswa dapat menemukan gaya belajar dengan cara mengisi nilai pada setiap sikap di kolom penelitian yang disediakan pada lembar angket belajar. Tidak ada jawaban yang benar dan salah pada tes gaya belajar ini, semua jawaban diisi dengan penelitian sesuai dengan sikap yang paling mendekati cara belajarnya. Penilaian tes gaya belajar diambil dari jumlah jawaban tertinggi dari skor setiap gaya belajar. 


\section{$\pi$ (Phi)}

Tes kemampuan berpikir intuitif dalam menyelesaikan soal matematika tahap I berisi 2 butir soal materi SPLTV.Soal tahap I diberikan terlebih dahulu dari soal tahap II. Sebelum soal tahap I diberikan kepada subjek penelitian terlebih dahulu harus divalidasi oleh beberapa ahli setelah divalidasi diujicobakan kepada siswa yang lebih dulu belajar SPLTV. Masalah pada lembar soal tahap II setara pada masalah lembar soal tahap I. Perbedaanya terletak pada bilangan/angka dan penyajian beberapa informasi yang terdapat pada soal.Pada penelitian ini uji kredibilitas data atau kepercayaan terhadap data hasil penelitian dilakukan dengan triangulasi waktu, yaitu menggunakan pengulangan wawancara, yakni mencari kesesuaian data yang bersumber dari dua masalah yang setara pada waktu yang berbeda.

\section{HASIL DAN PEMBAHASAN Hasil Instrumen Pengumpulan Data}

Hasil instrumen pengumpulan data pada penelitian ini adalah angket gaya belajar berdasarkan MBTI, nilai hasil belajar siswa, lembar tes soal matematika dan pedoman wawancara. Tes gaya belajar diadopsi langsung dari buku Tim Psikologi (Babon Psikotes Paling Update, 2014:181-186), instrumen lembar tes kemampuan berpikir intuitif dalam menyelesaikan soal matematika untuk mengetahui kemampuan berpikir intuitif dalam menyelesaikan soal matematika pada materi SPLTV berdasarkan indikator menyelesaikan soal matematika menurut Polya. Soal cerita ini terdiri dari dua soal esai yang terdiri dari tahap I dan tahap II.

Instrumen pedoman wawancara digunakan untuk menggali lebih mendalam mengenai kesulitan belajar matematika dalam menyelesaikan soal
cerita.Pertanyaan pada pedoman wawancara terdiri dari 15 pertanyaan kemudian dapat dikembangkan lagi sesuai dengan kondisi yang ada dan disesuaikan dengan langkah menyelesaikan soal cerita menurut Polya.

\section{Hasil Validasi Instrumen}

Lembar tes kemampuan berpikir intuitif dalammenyelesaikan soal matematika pada materi SPLTV. Soal tersebut disusun berdasarkan Kompetensi Dasar, Indikator Soal, dan Indikator menyelesaikan soalmatematika pada materi SPLTV SMA kelas $\mathrm{X}$ semester ganjil. Item soal tersusun sebanyak 2 item telah divalidasi oleh 1 orang ahli matematika dan 1 orang guru matematika yang ada di sekolah.

\section{Hasil Uji Coba Soal Kemampuan Berpikir Intuitif Dalam Menyelesaikan Soal Matematika}

Sebelum soal diberikan kepada sampel terlebih dahulu diujicobakan pada kelas di luar sampel yaitu kelas XI SMA Negeri 5 Batanghari yang berjumlah 32 siswa. Dari hasil uji coba tes kemampuan berpikir intuitifdalam menyelesaikan soal matematika diperoleh validitas soal, tingkat kesukaran, daya beda soal, dan reliabilitas soal. Berdasarkan hasil dari validitas soal kedua soal tersebut dinyatakan valid dan dapat digunakan peneliti untuk penelitian.

\section{Hasil Instrumen Pengumpulan Data}

Setiap siswa pada penelitian (kelas X MIA 1- MIA 5) akan diberi angket gaya belajar. Hasil dari perhitungan angket gaya belajar didapatkan 43 siswa bertipe kepribadian lebih dari satu (campuran), 9 siswa bergaya belajar ekstrovert, 14 siswa 
bergaya belajar introvert, 18 siswa bergaya belajar sensing, 6 siswa bergaya belajar intuition, 8 siswa bergaya belajar thinking, 11 siswa bergaya belajar feeling, 40 siswa bergaya belajar judging dan 11 siswa bergaya belajar perceiving. Dikarenakan gaya belajar judging merupakan gaya belajar yang dominan di kelas X maka pada penelitian ini dipilih gaya belajar judging sebagai subjek penelitian.

Instrumen lembar tes kemampuan berpikir intuitif dalam menyelesaikan soal matematika untuk kemampuan berpikir intuitif dalam menyelesaikan soal matematika pada materi SPLTV berdasarkan indikator menyelesaikan soal matematika menurut Polya. Soal matematika ini terdiri dari dua soal esai yang terdiri dari tahap I dan tahap II, lalu diberikan kepada siswa judging yang berjumlah 40 siswa yang memiliki kemampuan tinggi, sedang, dan rendah yang didapatkan dari hasil nilai ulangan harian. Pada saat pemberian soal matematika siswa hadir semua, sehingga peneliti tidak mengalami kendala dan penelitian dapat berjalan dengan lancar.Berdasarkan teknik pengambilan sampel seperti langkahlangkah di atas, maka diperoleh 2 siswa untuk selanjutnya melakukan wawancara sesuai pedoman wawancara. Pengambilan 2 siswa tersebut ditentukan oleh peneliti bersama guru bidang studi matematika yang lebih mengetahui tingkat kemampuan serta kebiasaan siswa ketika proses pembelajaran. Perhitungan data penentuan subjek penelitian dapat dilihat pada lampiran lampiran 20 dan lampiran 22, serta 2 siswa tersebut disajikan dalam tabel berikut:

Tabel 2. Daftar Nama Subjek Penelitian

\begin{tabular}{cccc}
\hline No & Nama & Keterangan & Kode Subjek \\
\hline 1 & Nurdiah Akmawati & Tinggi & STJ \\
2 & Ivan Sepria W. & Sedang & SSJ \\
\hline
\end{tabular}

\section{Hasil Penelitian Kemampuan Berpikir Intuitif Siswa Gaya Belajar Judging dalam Menyelesaikan Soal SPLTV}

\section{Analisis Kemampuan Berpikir Intuitif STJ dalam Menyelesaikan Soal SPLTV}

STJ dalam memahami soal subjek menjawab langsung,teratur dan terurut dalam menjawab soal yang diberikan oleh peneliti dan menggunakan langkah-langkah dan pengalamannya, shingga dapat dikatakan STJ menggunakan intuisi yang merupakan karakter berpikir intuitif cammon sense. Dalam membuat rencana pemecahan soal STJ menggunakan semua informasi yang penting dan menyeluruh, sehingga dapat dikatakan STJ menggunakan karakter berpikir intuitif
globality.Dalam melaksanakan rencana penyelesaian soal STJ melaksanakan rencana yang dipilih sebelumya, sehingga STJ dapat dikatakan tidak menggunakan intuisi. Dalam melihat kembali kebenaran penyelesaian soal STJ menggunakan cara lain yang dianggapnya benar, sehingga dapat dikatakan STJ menggunakan karakter berpikir intuitif intrinsic certainty dan subjek juga memiliki argumen yang kokoh dan stabil, maka dapat dikatakan bahwa STJ menggunakan karakter berpikir intuitif perseverance.

\section{Analisis Kemampuan Berpikir Intuitif SSJ dalam Menyelesaikan Soal SPLTV}

SSJ dalam memahami soal secara otomatis, terurut dan teratur 


\section{$\pi$ (Phi)}

meskipun lebih dari satu kali dalam membaca soal, serta SSJ menggunakan pengetahuan dan pengalamannya pada saat belajar di kelas, sehingga dapat dikatakan SSJ menggunakan karakter berpikir intuitif common sense. Dalam merencanakan penyelesaian soal SSJ menggunakan informasi penting yang terdapat dalam kata-kata pada soal yang muncul setelah berusaha mencermati informasi pada soal, sehingga dapat dikatakan bahwa SSJ menggunakan karakter intuitif globality.Dalam melaksanakan rencana penyelesaian soal SSJ menggunakan langsung rencana yang dipilihnya, sehingga dapat dikatakan bahwa SSJ tidak meggunakan intuisi dalam melaksanakan rencana penyelesaian soal. Dalam melihat kembali penyelesaian soal yang telah dibuat SSJ tidak menggunakan cara lain, subjek hanya mengulangi menghitung lagi, sehingga dapat dikatakan bahwa SSJ tidak menggunakan intuisi.

\section{SIMPULAN DAN SARAN}

Berdasarkan hasil penelitian dapat disimpulkan bahwa kemampuan berpikir intuitif siswa yang memiliki gaya belajar tipe judging dalam menyelesaikan soal matematika pada materi SPLTV di kelas X SMA Negeri 5 Batanghari tahun ajaran 2017/2018. Dapat diuraikan terlebih dahulu yaitu dari 161 siswa kelas X MIA1-5 SMA Negeri 5 Batanghari yang mengikuti tes gaya belajardidapatkan 43 siswa bertipe kepribadian lebih dari satu (campuran), 9 siswa bergaya belajar ekstrovert, 14 siswa bergaya belajar introvert, 18 siswa bergaya belajar sensing, 6 siswa bergaya belajar intuition, 8 siswa bergaya belajar thinking, 11 siswa bergaya belajar feeling, 40 siswa bergaya belajar judging dan 11 siswa bergaya belajar perceiving. Selanjutnya, diambil 2 siswa gaya belajar judging dengan kategori tinggi dan sedang berdasarkan hasil nilai ulangan harian siswa, kemudian dilakukan tes kemampaun berpikir intuitif dalam menyelesaikan soal SPLTV selanjutnya dilakukan wawancara. Dari hasil wawancara yang telah dilakukan peneliti sebanyak dua kali terhadap subjek penelitian ternyata hasilnya telah akurat, karena antara data I dan data 2 tidak terdapat perbedaan yang signifikan, sehingga terdapat kesesuaian data atau data telah jenuh.

Tahap dalam menyelesaikan soal matematika yaitu (1) Memahami soal, (2) Merencanakan Penyelesaian soal, (3) Melaksanakan rencana penyelesaian soal, (4) Melihat kembali kebenaran penyelesaian soal yang telah dibuat dan indikator berpikir intuitif yang di amati menurut Westcott yaitu (1) catalic inference (2) power of synthesis (3) cammon sence serta adapun sifat-sifat lainnya menurut Fischbein (Muniri, 2013) diantaranya:(1) self-evident, (2) intrinsic certainty, (3) perseverance, (4) coerciveness, (5) extrapolativaness, (6) globality, dan (7) implicitness. Hasil penelitian menunjukkan bahwa (1) karakter berpikir intuitif yang digunakan STJ dalam menyelesaiakan soal SPLTV antara lain: common sense, globality, intrinsic certainty dan perseverance. (2) karakter berpikir intuitif yang digunakan SSJ dalam menyelesaiakan soal SPLTV antara lain: common sense, globality.

\section{DAFTAR PUSTAKA}

Arikunto, Suharsimi. 2010. Prosedur Penelitian (Edisi Revisi 2010). Jakarta: Rineka Cipta.

Arikunto, Suharsimi. 2012. DasarDasar Evaluasi Pendidikan (Edisi 2). Jakarta: Bumi Aksara. 


\section{$\pi$ (Phi)}

Fitriani, S. (2017).Analisis Kemampuan Penalaran Analogi Siswa Berdasarkan Tipe Kepribadian MBTI (MAYERS-BRIGGS TYPE INDICATOR) Dalam Menyelesaikan Soal Hubungan Gradien Pada Siswa Kelas VIII SMP Negeri 16 Sarolangun: Jurnal Ilmiah Pendidikan Matematika Universitas Batanghari Jambi.1(1).

Ghufron, M. Nur dan Risnawita, Rini. 2014.Gaya Belajar Kajian Teoritik. Yogyakarta : Pustaka Pelajar.

Moleong, Lexy J. 2012. Metodologi Penelitian Kualitatif. Bandung: PT REMAJA ROSDAKARYA.

Mudrika, Nafis. 2013. E-book MBTI (Myer Briggs Type Indicator).

Muniri. 2013. "Karakteristik Berpikir Intuitif Siswa dalam Menyelesaikan Masalah Matematika". Jurnal pendidikan matematika

Psikologi, Tim Bintang. 2017. Top Update Diktat Resmi Psikotes. Jakarta: Bintang Wahyu.

Sudjana, Nana. 2016. Penilaian Hasil Proses Belajar Mengajar.Bandung: PT REMAJA ROSDAKARYA.

Sugiyono. 2012. Metode Penelitian Kuantitatif, Kualitatif dan $R \& D$. Bandung: CV. Alfabeta.

Solaikah, dkk. 2013. "Identifikasi Kemampuan Siswa dalam Menyelesaikan Soal Aritmatika Sosial ditinjau dari Perbedaan Kemampuan Matematika". Jurnal Pendidikan Matematika STKIP PGRI Sidoarjomudrika.

Tim Psikologi. 2014. BABON PSIKOTES PALING UPDATE. Jakarta: Jagakarsa.

Tohirin.2013. Metode Penelitian Kualitatif dalam Pendidikan dan
Bimbingan Konseling.Jakarta: Rajawali Pers.

Usodo, Budi. 2012. Karakteristik Intuisi Siswa SMA dalam Memecahkan Masalah Matematika Ditinjau dari Kemampuan Matematika dan Perbedaan Gender. 1 (1). 